\title{
The corrosion behaviour of nanograined metals and alloys ${ }^{(*)}$
}

\author{
P. Herrasti ${ }^{*}$ C. Ponce de León ${ }^{* *}$ and F.C. Walsh ${ }^{* *}$
}

\begin{abstract}
There has been considerable interest in the properties of nanocrystalline materials over the last decade. Such materials include metals and alloys with a crystal size within the order of 1 to $100 \mathrm{~nm}$. The interest arises due to the substantial differences in electrical, optical and magnetic properties and also due to their high adsorption capability and chemical reactivity compared to their larger grained counterparts. In this paper, the corrosion of nanocrystalline metals and alloys is investigated and compared to the corrosion of microcrystalline materials having a similar composition. The focus is on the corrosion of nickel, copper, cobalt and iron alloys. Key aspects of different corrosion behaviour such grain boundaries and size are identified.
\end{abstract}

\section{El comportamiento de la corrosión de los metales y aleaciones nanogranulados}

\begin{abstract}
Resumen
En la última década ha habido un gran interes en las propiedades de materiales nanocristalinos. Estos materiales incluyen metales y aleaciones con un tamaño de cristal del orden de 1 a $100 \mathrm{~nm}$. El interes por estos materiales es debido a las grandes diferencias en cuanto a sus propiedades electricas, opticas y magneticas, asi como a su alta capacidad de adsorción y reactividad química en relación a los mismos materiales con tamaños de grano mayores. En este trabajo se ha investigado y comparado la corrosión de materiales nano y microcristalinos de similar composición química. Principalmente se ha centrado en la corrosión de metales tales como niquel, cobre, cobalto y aleaciones de hierro. Se ha comprobado que los diferentes comportamientos frente al proceso de corrosión están intimamente ligados con los bordes de grano y el tamaño de dichos granos.
\end{abstract}

Palabras clave

Aleaciones; Corrosión; Metales; Nanocristales.

\section{INTRODUCTION AND SCOPE}

A wide variety of metals and alloys consist of small crystal grains and can be classified as nanostructured (NS) or nanocrystalline solids (NCs). There are clear differences between these two nanomaterials; the NC solids do not follow a regular orderly pattern while the NS are considered as NCs with a regular repeated patterns containing orderly formations and, usually, a template is required to obtain them. Although these nanocrystaline materials have always existed in nature, our understanding of their properties and their influence on the environment surround them is limited. Their properties and applications are fundamental to the development of new materials and they have been the subject of intense research over the last two decades. Their formation has gained much importance due to their unusual properties compared to microcrystalline (MC) materials. Examples of nanomaterials include aluminium nanoparticles of 20 to $30 \mathrm{~nm}$ which can spontaneously combust while bulk aluminium is stable ${ }^{[1]}$ and calcium carbonate which can form either a fragile chalk or tough abalone shells, depending on the structural arrangement of the molecules ${ }^{[2]}$. The applications of these nanostructures are large and diverse, they include: conductive plastics ${ }^{[3]}$ anticorrosive coatings ${ }^{[4]}$, fuel cells and batteries ${ }^{[5 \text { and } 6]}$, solar energy generation ${ }^{[7 \text { and } 8]}$ electricity carriers ${ }^{[9]}$, fire resistant materials ${ }^{[10]}$, computing and data storage ${ }^{[11]}$, sensors $^{[12 \text { and } 13]}$, water treatment ${ }^{[14]}$, catalysis ${ }^{[15]}$ and early identification of cancer cells ${ }^{[16]}$. Although many of these applications still remain untested, the research

(•) Trabajo recibido el día 30 de julio de 2012 y aceptado en su forma final el día 11 de septiembre de 2012.

* Universidad Autónoma de Madrid. Facultad de Ciencias. Departamento de Química-Física Aplicada. 28049, Spain. (pilar.herrasti@uam.es).

** Electrochemical Engineering Laboratory, National Centre for Advanced Tribology, School of Engineering Sciences, University of Southampton, Highfield, Southampton SO17 1BJ, United Kingdom. (capla@soton.ac.uk) 
and development investment over the last ten years has been substantial; in the USA, more than a billion dollars were allocated in $2005^{[17]}$ and more recently Japan and the European Union invested 770 and 1400 million euros respectively, in scientific programs involving nanomaterials ${ }^{[18]}$.

There is concern that the models established to predict the properties of bulk materials are not be applicable to estimate the behaviour of nanocrystalline materials whether they are metal, metal oxides, alloys, carbon or composites. Their toxicity, health implications and durability are still under review. For example, it has been publicised that titanium dioxide particles used in sunscreen might produce free radicals when exposed to sunlight, increasing the risk of cancer ${ }^{[19]}$. The behaviour of these $\mathrm{NC}$ in industrial or domestic applications is very important and needs to be evaluated to establish aspects such as durability, cost and efficiency and safety. There is also the need to understand their corrosion behaviour mainly in metals and alloys of general use.

\subsection{General characteristics of nanomaterials}

Despite their potential applications and explosion in research interest, there is little published work on the degradation of nanostructured metals. In the case of metal oxides there has been a study of the effect of long term immersion of hydrothermally synthesised nanometre titanium oxide nanotubes in aqueous acids ${ }^{[20]}$. The authors found that long term immersion resulted in their transformation to rutile with the loss of nanostructured properties. In the case of metals the clear distinction between nanostructures (NS) and microstructures (MS) lies in their length dimensions; NS can be defined according to their geometrical dimension which falls between molecular and microscopic scales. When describing a NS it is necessary to differentiate between the numbers of dimensions on the nanoscale. The formation of a nanotextured surfaces has at least one nanoscale dimension, i.e., the thickness of an object which could be between 0.1 and $100 \mathrm{~nm}$. Nanotubes have two dimensions on the nanoscale, i.e., a diameter that can vary between 0.1 and $100 \mathrm{~nm}$ and a length which could be much larger. Semi-spherical, rods or flat plate shape nanoparticles have three nanoscale dimensions i.e., the particle can be between 0.1 and $100 \mathrm{~nm}$ in each spatial dimension.

A clear example to illustrate the nature of nanostructure is in materials such as silicon; the silicon band gap is not affected in pieces of $0.1 \mu \mathrm{m}$
( $=100 \mathrm{~nm})$ sizes but by reducing the crystal to a few $\mathrm{nm}$ the band gap increases and the silicon emits visible light. This effect is largely due to the high surface-to-volume ratio of the NS materials. A 1000 -atom nano-cluster will have approximately $25 \%$ of its atoms on the surface which means that free nanoclusters exhibit a high density of unsatisfied, dangling bonds and, correspondingly, high surface free energy. Another example is the case of carbon nanotubes (CNTs) which can often be considered as wrapped sheets of $\mathrm{sp}^{2}$ hybridized carbon presenting metal or semiconductor characteristics depending on the wrapping angle and the diameter of the nanotube $e^{[21]}$.

Most engineering materials are polycrystalline (PC) in nature with grain sizes in the order of $\mu \mathrm{m}$ or more and comprise many small single disoriented crystals which meet at internal interfaces, namely, the grain boundaries. These interfaces, frequently planar in shape, have a two-dimensionally periodic atomic structure. A PC cube of $1 \mathrm{~cm}^{3}$ dimension containing grains of $10 \mathrm{~nm}$ diameter on each edge will expose $10^{6}$ grains per edge summing a total boundary contact area with their neighbouring grains of several square metres. Thus, grain boundaries play an important role for controlling the electrical, mechanical and morphological properties of a PC solid. These properties are influenced by the detailed atomic structure of the grain boundaries, as well as by defects such as dislocations and grain edges. Grain boundaries generally have very different atomic configurations and local atomic densities than those of a perfect crystal so they attract impurities which tend to concentrate and segregate at the interfaces between grains and grain boundaries.

NC materials can consist of two different types of atomic structures namely a long-range-order crystalline structure for all the atoms far from the grain boundaries and a short-range-order disordered structure with some at the interfacial region, which is more comparable to a gas-phase structure. It is the presence of two structural components (crystallites and interfacial component) of comparable volume fractions that characterise $\mathrm{NC}$ materials and has been claimed to be the origin of novel and improved properties ${ }^{[22]}$. It has been shown that the triple junction and grain boundary volume fraction depend strongly on grain sizes, especially below $30 \mathrm{~nm}^{[23]}$. Figure 1 shows the volume fraction associated with grain boundaries and triple junctions as a function of the grain size and boundary thickness of a 14 side tetrakaidecahedron modelled by Palumbo et al. ${ }^{[23]}$.

The results of this model indicate that, for sizes larger than $30 \mathrm{~nm}$, the triple volume fraction 
THE CORROSION BEHAVIOUR OF NANOGRAINED METALS AND ALLOYS EL COMPORTAMIENTO DE LA CORROSIÓN DE LOS METALES Y ALEACIONES NANOGRANULADOS

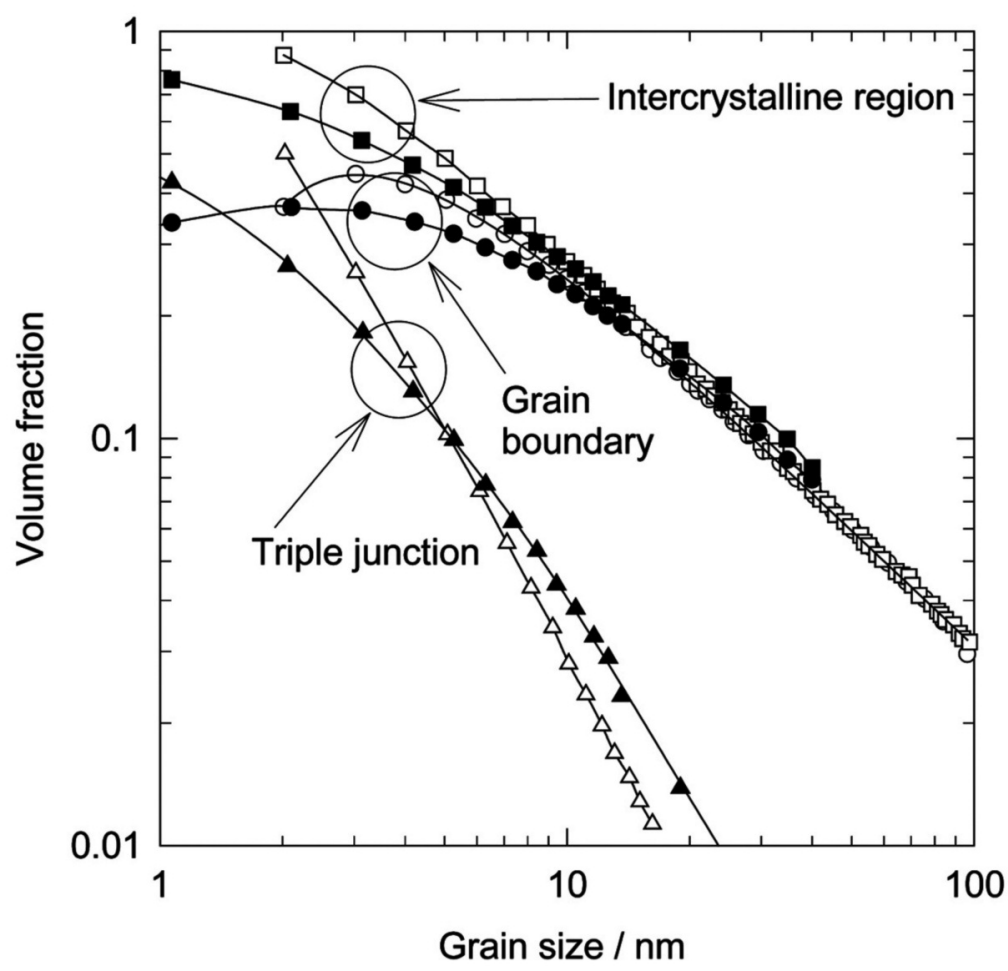

Figure 1. Effect of grain size on the calculated volume fractions for intercrystalline regions, grain boundaries and triple junction. Interface region: $\square^{[23]}, \boldsymbol{\square}^{[24]}$. Grain boundary: $\triangle^{[23]}, \Delta^{[24]}$. Triple junction: $\bigcirc^{[23]}, \bullet^{[24]}$.

Figura 1. Efecto del tamaño de grano sobre la fracción de volumen calculada para regiones intercristalinas, bordes de

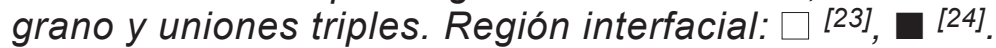
Bordes de grano: $\triangle{ }^{[23]}, \Delta^{[24]}$. Uniones triple: $\bigcirc^{[23]},{ }^{[24]}$.

contribution to the total interface volume fraction is negligible making clear that in large grain sizes, the intercrystalline volume fraction consists mainly of contributions for the grain boundary atoms. In contrast, when the grain size is lower that $30 \mathrm{~nm}$, the triple junction volume contributes to a greater extent to the total interface volume fraction than the grain boundary volume fraction. In fact triple junctions and grain boundaries equally contribute to the total interface component for very small grain sizes except for grains $<3 \mathrm{~nm}$ where the triple junction contribution dominates ${ }^{[24]}$.

The changes in the properties and their applications strongly depend on whether or not the materials can keep the new acquired properties over time. However, one of the most likely problems to occur to the NC is corrosion. This process, which corresponds to the thermodynamically favourable formation of oxides or cations of the metal, is one of the main problems when the materials are used in corrosive environments, especially those having high humidity or elevated temperature ${ }^{[25]}$. Equipment damage due to corrosion attacks constitutes over $5 \%$ of the gross national product of many countries. Despite its importance, the degradation of $\mathrm{NC}$ has received little attention. $\mathrm{NC}$ metals and alloys have gain considerable importance in industrial applications which require good understanding of the corrosion properties of the materials as a function of the grain size.

According to classic corrosion theory, NC materials should have a very poor corrosion resistance due to the large quantity of grain boundaries. The boundaries function as preferential paths to accelerate corrosion due to the large number of nano electrochemical cells within the matrix. There are two reasons why NC materials might have altered corrosion and reactivity unlike other forms of the same materials; firstly, the change in the energy levels due to quantum effects that alter the chemistry and reactivity of nanosized structures and makes them react different than the bulk material, secondly, the 
size of the structures in a NC "bulk" material. Often, localized corrosion at grain boundaries or other defects lead to crevice corrosion, cracking or material failure. Material with grain or fracture size in the order of $\mathrm{nm}$ may not have selected regions where the local chemistry is significantly different than other regions. Thus, regions giving rise to selective attack originating from localized corrosion may be absent. If the corrosion resistant and wear processes of $\mathrm{NC}$ materials in the environment where they are to function are not stable, they will not survive long enough to have a practical application. It is, therefore, important to assess the effect of $\mathrm{NC}$ formation on the corrosion resistance of these materials.

Current data on corrosion of $\mathrm{NC}$ materials is somehow limited and the reported results show both detrimental and beneficial effects. The objective of this paper is to compare the corrosion of nano and microcrystalline structures of metal and alloys used in the industry on different applications and understand their behaviour in different corrosive environments. The first part is dedicated to metals and its alloys, in both cases the electrolytes and their effect on the nano and microstructured materials will be analysed. This will be followed by the analysis of more complex alloys where not only the nanostructure is important during the corrosion process but also the added metal components within the alloy. An analysis of the most important factors affecting the corrosion between nano crystal materials and micro crystals will be presented.

\section{MANUFACTURE OF NANOSTRUCTURES}

\subsection{Nickel and its alloys}

The electrochemical behaviour of nickel and its oxides is important for applications such as rechargeable batteries, fuel cells, catalysis and decorative coatings. Nickel is more active than aluminium, manganese and zinc in the electromotive force series. In the presence of oxygen and slightly acidic media nickel undergoes pitting corrosion by chloride ions while in the absence of oxygen nickel forms a stable passive hydroxide film, $\mathrm{Ni}(\mathrm{OH})_{2}$. The influence of the grain size and how effective this can be for the protection against corrosion also depends on the type of electrolyte surrounding the sample.

Wang et al. ${ }^{[26]}$ studied the corrosion of electrodeposited NC nickel coatings in a $10 \% \mathrm{NaOH}$ solution with different grain sizes. The electrodes were polarized to overpotentials more positive than
$0.2 \mathrm{~V}$ vs. SCE and showed the formation of a typical passive layer that involved water molecules absorbed on the electrode surface forming $\mathrm{Ni}(\mathrm{OH})_{2}$ films. The mechanism to produce the passive layer involves the following chemical and electrochemical steps (a CEC

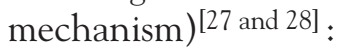

$$
\begin{array}{lr}
\mathrm{Ni}+\mathrm{H}_{2} \mathrm{O} \rightarrow \mathrm{Ni}\left(\mathrm{H}_{2} \mathrm{O}\right)_{\text {ads }} & \text { Chemical (1) } \\
\mathrm{Ni}\left(\mathrm{H}_{2} \mathrm{O}\right)_{\text {ads }} \rightarrow \mathrm{Ni}(\mathrm{OH})^{+}+\mathrm{H}^{+}+2 \mathrm{e}^{-} & \text {Electrochemical (2) } \\
\mathrm{Ni}(\mathrm{OH})^{+}+\mathrm{OH}^{-} \rightarrow \mathrm{Ni}(\mathrm{OH})_{2} & \text { Chemical (3) }
\end{array}
$$

Figure 2 shows an example of polarization curves for NC nickel coatings with different grain size in $10 \% \mathrm{NaOH}$ solution.

The open-circuit potential shifts to more negative potentials and the corrosion rate fall when the grain size decreases. The passive zone increases as the grain size decreases and, in all cases, an increase in the anodic current can be observed after the passive zone, indicating that the passive layer has broken and the substrate has pitted. Electrochemical impedance spectroscopy (EIS) and linear polarization (LP) results on nickel deposits are consistent in that both techniques demonstrate an increased corrosion resistance for NC coatings when the crystal size is lowered from $3 \mu \mathrm{m}$ to $16 \mathrm{~nm}$. This increase in corrosion resistance is believed to be improved by the rapid formation of continuous nickel hydroxide passive films on the surface of crystalline defects. The relatively higher integrity of this passive film is attributable to the continuous, smooth and protective nature of the film formed on NC coatings.

When NC nickel is immersed in $\mathrm{NaOH} 30 \%$ wt. and $\mathrm{NaCl} 3 \%$ wt. the metal exhibits high corrosion rates but was more immune to localised attacks than a coarse grain (CG) nickel ${ }^{[29]}$. Localised attack has catastrophic consequences in coarse grained metals when are in constant use.

Other authors have found that a passive layer on the nanocrystalline nickel surface can be formed on the deposits in a solution containing $1 \mathrm{M} \mathrm{H}_{2} \mathrm{SO}_{4}{ }^{[30]}$. In addition, the $\mathrm{NC}$ materials showed larger passivity currents compared with the CG nickel showing that the passive layer on top of NC samples contains defects and therefore prone to form additional passive layers. A shift on the open-circuit potential (OCP) towards positive values has been observed in $\mathrm{NC}$ nickel which is not observed in CG nickel. The authors attribute this shift to the substantial quantity of defects such as dislocations and grain boundaries that catalyse the hydrogen evolution process in $\mathrm{NC}$ materials. 


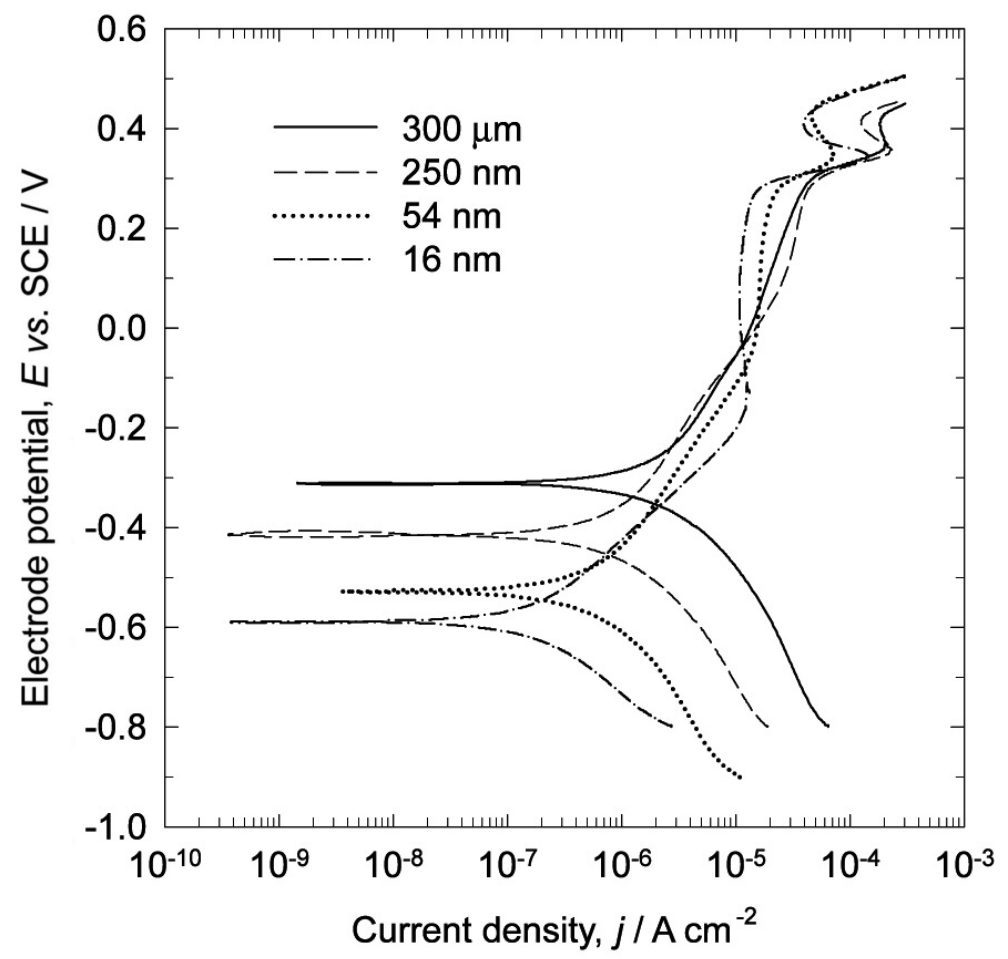

Figure 2. Polarization curves of nickel films of different grain sizes in $10 \%$ wt. $\mathrm{NaOH}{ }^{[26]}$.

Figura 2. Curvas de polarización de películas de níquel con diferentes tamaños de grano en $10 \%$ en peso $\mathrm{NaOH}^{[26]}$.

Rofagha et al. ${ }^{[31]}$ demonstrated that, under potentiostatic conditions at $1.2 \mathrm{~V}$ vs. SCE in $2 \mathrm{M}$ $\mathrm{H}_{2} \mathrm{SO}_{4}$ for 2000 s, NC nickel corroded uniformly while the CG material showed extensive localized attacks along the grain boundaries and triple junctions. While the thickness of the passive layer was the same on both specimens, X-ray photoelectron spectroscopy showed more defective passive layers in the case of the NC sample than that formed on the $\mathrm{CG}$ specimens. This higher defective passive film on the NC specimen allowed for a more uniform break down of the film, which in turn led to a more uniform corrosion. In contrast, the breakdown of the passive film in the CG nickel occurred first at the grain boundaries and triple junctions rather than on the crystal surface, leading to a preferential attack at these points. Gonzalez et al. ${ }^{[32]}$ have shown that NC nickel of $100 \mathrm{~nm}$ was intrinsically resistant to intergranular processes such as intergranular attack and intergranular stress corrosion cracking. This material was resistant to pitting attack and only slightly susceptible to crevice corrosion.

A similar corrosion study of NC nickel films synthesized by pulsed-jet electrodeposition has been reported $^{[33]}$. The electrochemical test was conducted in a mixture of $0.1 \mathrm{M} \mathrm{H}_{2} \mathrm{SO}_{4}$ and $1 \% \mathrm{NaCl}$. The authors found that nickel films in this media with the smallest grain size exhibited the highest corrosion current density and the worst corrosion resistance. Passive films were not formed in this case and the high corrosion behaviour can be explained in terms of the bond-order-length-strength correlation mechanism which suggests that the under coordinated atoms on the surface or grain boundaries are the cause of the observed phenomena. The atoms in the grain boundaries possess higher energy in an unstable status and can be easily attacked if the electrolyte does not promote the formation of a passive layer. In this case, the use of nanocrystalline materials in acidic media containing chloride would be detrimental and rapid, localised attack is expected.

Recent work ${ }^{[34]}$ has attempted to explain the high corrosion resistance of NC nickel obtained by electrodeposition compared with CG under salt spray conditions ( $5 \%$ wt. $\mathrm{NaCl}+$ less than $200 \mathrm{ppm}$ total solids at $\mathrm{pH} 7$ ). The authors used electron backscattered diffraction, EBSD, to generate orientation maps and assess the changes of the grain 

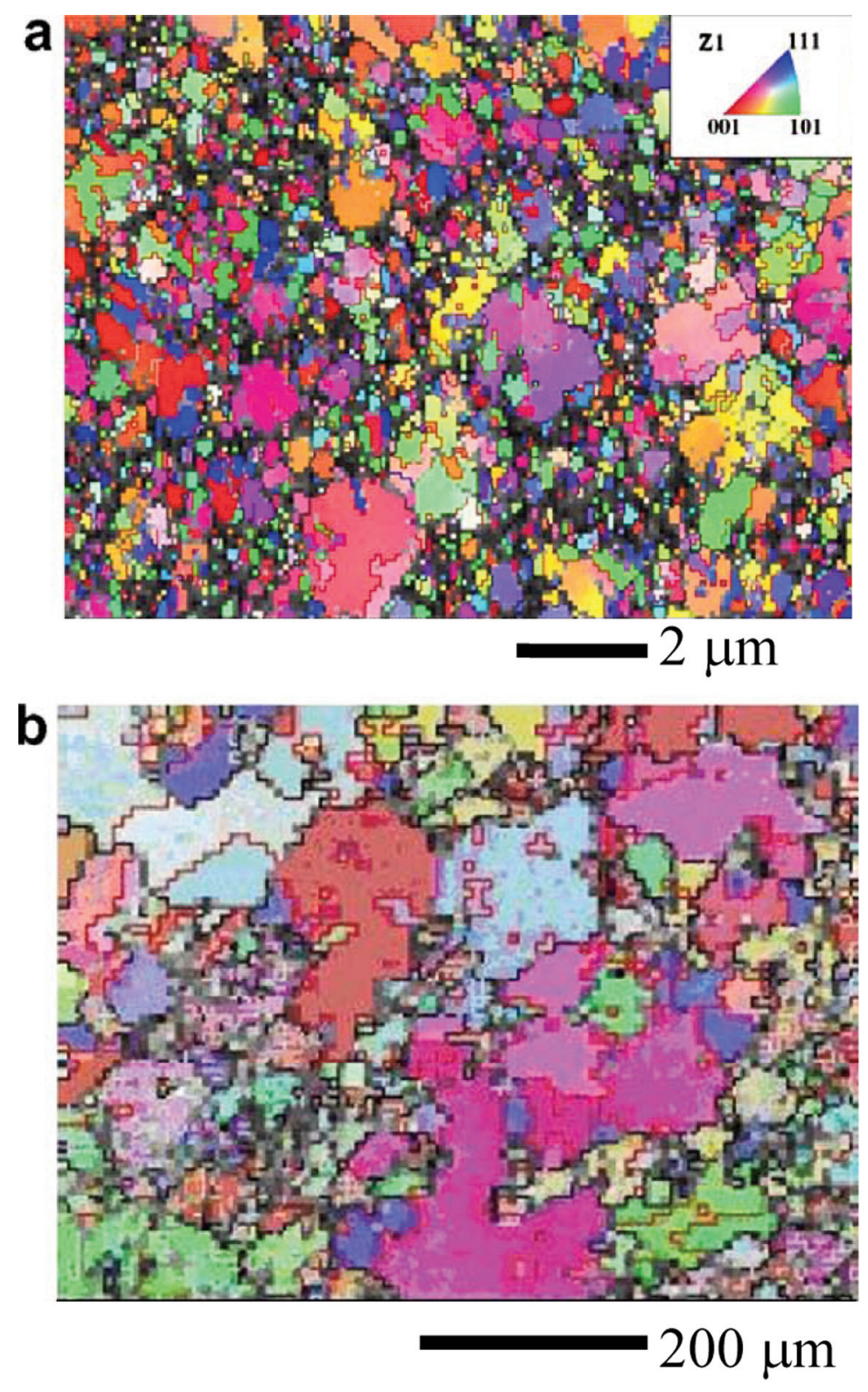

Figure 3. Orientation map for a) NS-Ni obtained using a sampling step size of $80 \mathrm{~nm}$ and b) CG-Ni obtained using a sampling step size of $18 \mu \mathrm{m}{ }^{\text {[32] }}$.

Figura 3. Mapa de orientación para a) NS-Ni obtenido usando un tamaño de salto de $80 \mathrm{~nm}$ y b) CG-Ni obtenido usando un tamaño de salto de $18 \mu m^{[32]}$.

boundaries. Figure 3 shows the low-angle- (LAGB) and high-angle- (HAGB) grain boundaries and the special coherent low sigma (CSL) boundaries for NS and CG deposits.

The statistic analysis of the images shows that the NC material contains $65 \%$ of CSL while the coarse grain metals contain $35 \%$. The authors conclude that the higher corrosion resistance of the NC materials can be attributed to the larger volume fraction of naturally occurring CSL boundaries.
Some properties of nickel materials can be improved by forming alloys with other metals. For example, Ni$\mathrm{Cu}$ alloys are known for their high pitting resistance in sea water ${ }^{[35]}$. Despite this, research to improve their corrosion resistant is still being pursued in order to increase the range of applications. The corrosion behaviour of these alloys is well known and many studies and data are available in the literature on the corrosion behaviour of conventional microcristalline alloys. S.K. Ghosh et al. ${ }^{[36]}$ studied dense NC Ni-Cu 
alloys of 2 to $30 \mathrm{~nm}$ grain size prepared by pulsed current (pc) and direct current (dc). The corrosion behaviour was studied in $3 \%$ wt. $\mathrm{NaCl}$ solution under aerated and air free conditions. They concluded that the corrosion resistance of the samples prepared by pc was superior to the ones obtained by dc. The nanomaterials prepared by the two methods presented better anticorrosive properties than a Monel-400 alloy $(67 \% \mathrm{Ni}, 30 \% \mathrm{Cu}, 2 \% \mathrm{Fe}$ and $0.03 \% \mathrm{C}$ ) typically used in hot water tanks. The potential vs. time curves and the morphology of the samples after being exposed to the electrolyte can be seen in figure 4 .

The conventional alloy suffered moderate potential changes over time and the optical micrographs show few pitting nucleation sites at the start of the experiment which increased both in size and depth over time. In the case of the NC material the opencircuit potential changes during the experiment and contrary to the material prepared by pulse current, it shows a homogeneous corroded surface and very few pitting points. In summary the corrosion of the NC alloy presented several interconnected-low depth pitting points instead of the typical pitting corrosion observed in Monel-400 alloys. The authors concluded that the electrodeposited NC show superior pitting corrosion resistance to conventional polycrystalline Monel-400.

Various authors have studied the addition of phosphorus and the effect of grain size in nickel alloys ${ }^{[37-39]}$. In all cases it has been found that neither NC nor amorphous nickel exhibited significant passivation behaviour in sulphuric acid solution during potentiodynamic polarization. In general, the NC materials have a much higher corrosion density current, lower polarization resistance and thus much lower corrosion resistance than their amorphous counterparts. The corrosion films formed at various applied potentials showed an enrichment of elemental phosphorus compared to nickel, suggesting that nickel is preferentially dissolved during anodic polarization ${ }^{[37}$ and 39$]$. The films formed were non-protective because the defective NC surfaces also facilitated atom dissolution and oxidation of the phosphorous atoms from hypophosphite on the surface to soluble phosphate anions. At higher applied potentials, the thick porous films formed on the NC specimens provided a small

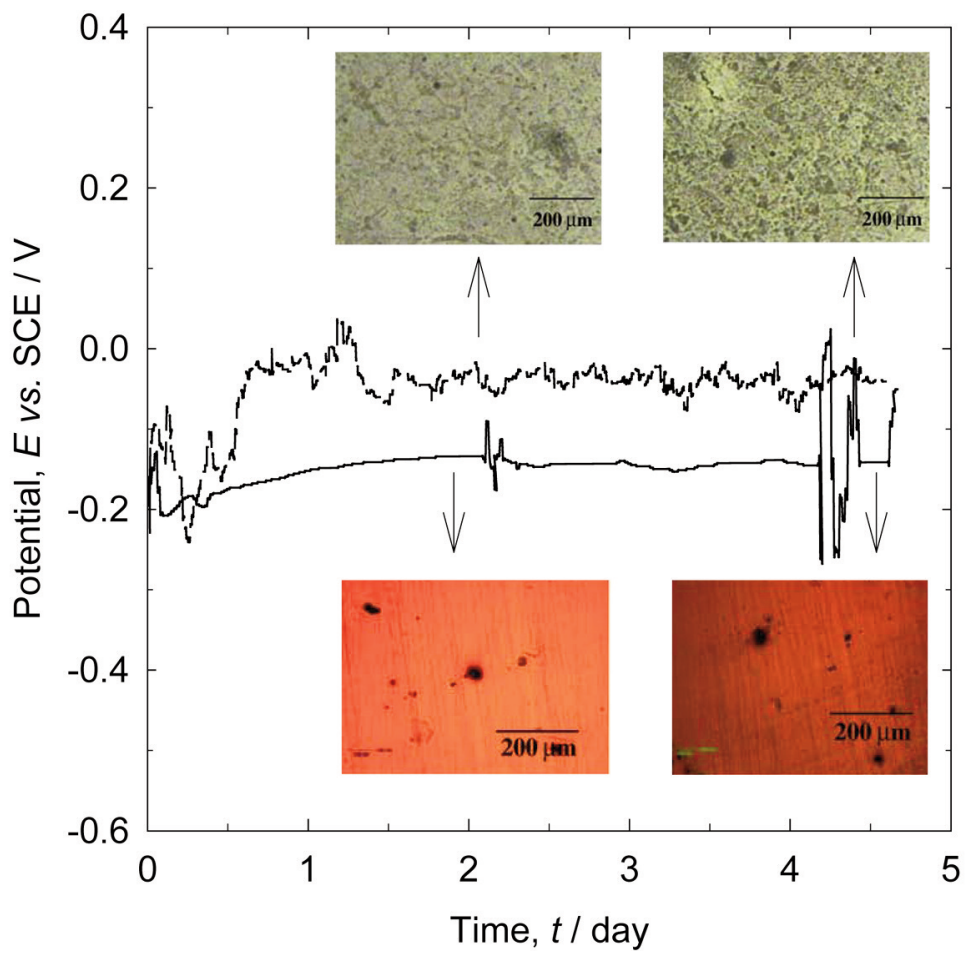

Figure 4. Potential vs. time plot at the OCP in free air-conditions for: a) conventional Monel-400 alloy and b) a Ni-Cu NC alloy, grain size in the range of 2-30 nm. Solution: $3 \% \mathrm{wt}$. $\mathrm{NaCl}{ }^{[34]}$.

Figura 4. Curvas potencial frente a tiempo a circuito abierto en condiciones libres de aire para a) aleación Monel-400 convencional y b) aleación Ni-Cu NC con tamaño de grano en el rango de 2-30 nm. Disolución: $3 \%$ en peso $\mathrm{NaCl}{ }^{[34]}$. 
kinetic barrier to further dissolution, resulting in slightly lowered anodic current densities.

Another interesting type of alloy that exhibits high hardness, good heat resistance and better corrosion behaviour, with respect to elemental nickel, includes $\mathrm{Ni}-\mathrm{W}$ and $\mathrm{Ni}-\mathrm{Fe}-\mathrm{W}$. The deposited nanocrystalline materials of these alloys have shown superior corrosion resistance due to preferential dissolution of nickel and formation of a rich tungsten film on the alloy surface ${ }^{[40]}$. During the corrosion process tungsten preferentially migrates toward the surface and forms protective oxides. The study of this alloy in $3.5 \% \mathrm{NaCl}$ shows that up to $7.54 \%$ wt. content of tungsten increased the corrosion resistance but higher percentages have a decrement effect. Similar results were found in the Ni-Fe-W alloy but not in the bimetallic alloy $\mathrm{Fe}-\mathrm{W}$ due the preferential dissolution rate of iron.

$\mathrm{Ni}-\mathrm{Sn}$ is another highly wear and corrosion resistant nickel alloy used as a protective coating for different metals and in surface finishing. The corrosion stability of this alloy has been attributed to the presence of stable, protective, self-limiting film of a glassy nickel polystannate on the alloy

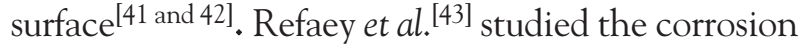
behaviour of $\mathrm{NC} \mathrm{Ni-Sn}$ alloy obtained electrochemically, in a chloride-fluoride bath in various concentrations of sodium chloride by cyclic voltammetry and impedance spectroscopy. The authors found higher corrosion resistance in the alloy with a negligible pitting corrosion compared to the two base metals, nickel and tin. They claimed that the high corrosion resistance was due to the formation of a thin passive film of tin and nickel oxides.

Table I summarizes the most relevant data from the literature of the corrosion resistance of $\mathrm{NC}$ nickel and its alloys in different electrolytic media compared with coarse grain (CG) nickel.

As the data shows the decrease in grain size causes a decrease in the corrosion current resulting in larger polarization corrosion resistance, regardless of the electrolyte media or whether nickel is pure or forming an alloy. This fact clearly indicates that the anticorrosive properties improve with the size of the structure due to the easily formed a passive layer and to a more generalized corrosion process than in the case of the

Table I. Summary of relevant data of the corrosion resistance of nickel and its alloys in different electrolytes. $E_{\text {corr }}=$ corrosion potential, $j_{\text {corr }}=$ corrosion current density, and $R_{p}=$ linear polarization charge transfer area resistance

Tabla I. Resumen de los datos más relevantes de la resistencia a la corrosión del niquel y sus aleaciones en diferentes electrolitos. $E_{\text {corr }}=$ potencial de corrosión, $j_{\text {corr }}=$ densidad de corriente de corrosión, y $R_{p}=$ resistencia de polarización

\begin{tabular}{|c|c|c|c|c|c|}
\hline Sample & $\mathrm{E}_{\text {corr }}$ vs. SCE/mV & $\mathrm{j}_{\mathrm{corr}} / \mu \mathrm{A} \mathrm{cm}{ }^{-2}$ & $\mathrm{R}_{\mathrm{p}} / \mathrm{k} \Omega \mathrm{cm}^{-2}$ & Conditions & Reference \\
\hline $\mathrm{Ni}(3 \mu \mathrm{m})$ & -312 & 0.575 & 326.6 & $10 \%$ wt. $\mathrm{NaOH}$ & [26] \\
\hline $\mathrm{Ni}(250 \mathrm{~nm})$ & -418 & 0.345 & 392.3 & & \\
\hline $\mathrm{Ni}(54$ nm) & -526 & 0.21 & 677.3 & & \\
\hline $\mathrm{Ni}(16 \mathrm{~nm})$ & -591 & 0.11 & 1068.0 & & \\
\hline Ni-P amorphous & -154 & 2800 & 3.28 & $0.5 \mathrm{~mol} \mathrm{dm}^{-3}$ & [39] \\
\hline Ni-P mix-structure & -437 & 100 & 0.058 & $\mathrm{H}_{2} \mathrm{SO}_{4}$ & \\
\hline Ni-P nanocrystalline & -430 & 1100 & 0.023 & & \\
\hline Ni-W-P amorphous & -216 & 7500 & 0.0042 & $0.5 \mathrm{~mol} \mathrm{dm}^{-3} \mathrm{H}_{2} \mathrm{SO}_{4}$ & \\
\hline Ni-W-P mix-structure & -344 & 12 & 0.383 & & \\
\hline NI-W-P nanocrystalline & -378 & 181 & 0.110 & & \\
\hline $\mathrm{Ni}-\mathrm{W}$ (W at $0.72 \%$ ) $40 \mathrm{~nm}$ & -520 & 0.8 & 0.285 & $3.5 \%$ wt. $\mathrm{NaCl}$ & [40] \\
\hline $\mathrm{Ni}-\mathrm{W}$ (W at $6.89 \%) 20 \mathrm{~nm}$ & -310 & 0.34 & 2.74 & & \\
\hline $\mathrm{Ni}-\mathrm{Cu}(12.7 \mathrm{~nm})$ & -294 & 0.11 & 37.5 & $3.5 \%$ wt. $\mathrm{NaCl}$ & [36] \\
\hline $\mathrm{Ni}-\mathrm{Cu}(15 \mu \mathrm{m})$ & -314 & 0.81 & 13.7 & & \\
\hline
\end{tabular}


counterpart coarse grain nickel. Despite this, some authors claim that the formation of an alloy can slow down the corrosion process; it is clear from the data that this is not the case for any of the alloys considered.

\subsection{Cobalt and its alloys}

Recently, nanocrystalline cobalt and cobalt-based alloys have been identified as promising candidates for the replacement of the highly toxic hexavalent chromium in plating baths, due to their excellent mechanical and wear resistant properties. These materials have shown a high saturation magnetization and good thermal stability. However, corrosion studies of cobalt and its alloys have been rather limited. Kim et al. ${ }^{[44]}$ investigated the effect of grain size on the corrosion characteristics of nanocrystalline cobalt with an average grain size of $13-15 \mathrm{~nm}$ in $0.25 \mathrm{M} \mathrm{Na}_{2} \mathrm{SO}_{4}$ by anodic polarization. They found that the overall shape of the anodic polarization curve for $\mathrm{NC}$ cobalt was very similar to that of its CG polycrystalline cobalt counterpart, including a similarity in both the corrosion potential, $E_{\text {corr }}$, and the lack of a clear evidence of passivation. They concluded that the corrosion behaviour of cobalt was not greatly affected by nanoprocessing, in fact a slightly enhanced anodic dissolution current was observed for NC cobalt. Aledresse and Alfantazi ${ }^{[45]}$ showed that both $\mathrm{NC}$ cobalt (67 nm grain size) and NC Co-P (50 nm grain size) did not passivate and the corrosion current densities for both increased markedly by a factor of 2 and 20 times, respectively, when compared to that of CG cobalt in $0.25 \mathrm{M} \mathrm{Na}_{2} \mathrm{SO}_{4}$ solution at $\mathrm{pH}$ 10.5.

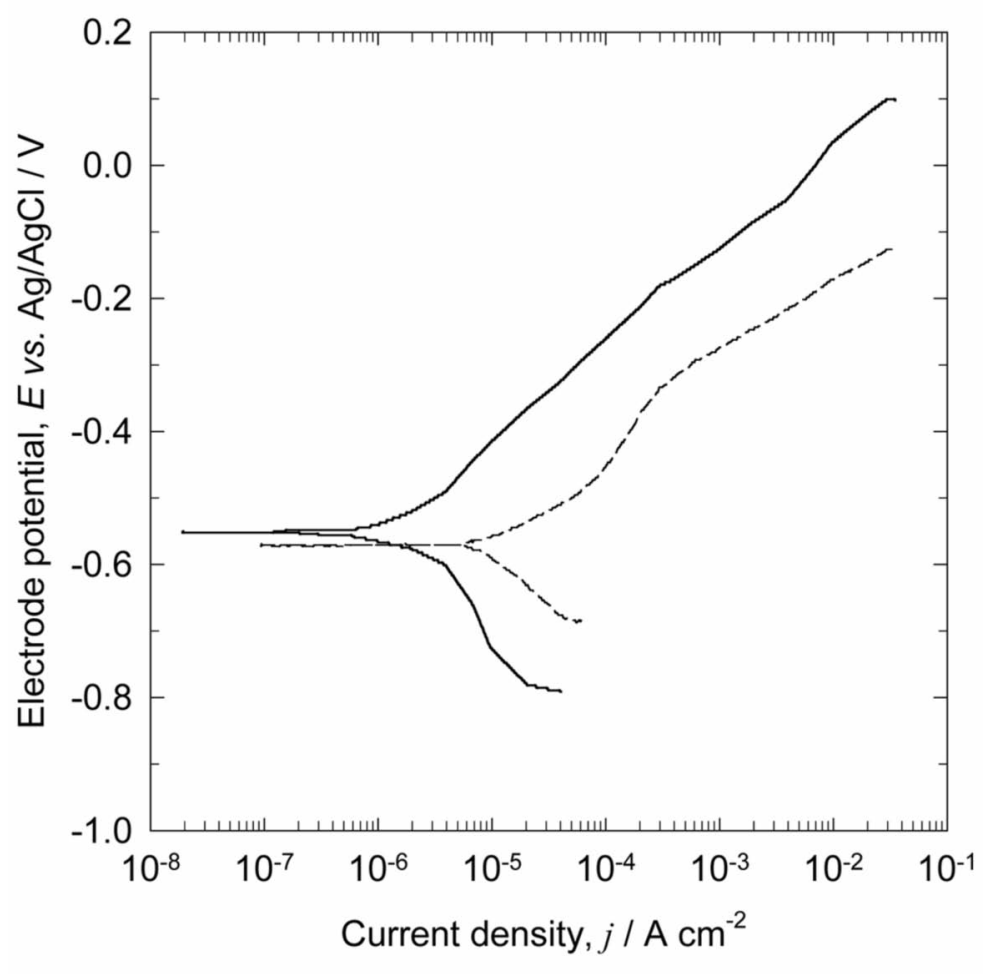

Figure 5. Potentiodynamic anodic polarization curves for the nanocrystalline cobalt $(67 \mathrm{~nm})(---)$ and conventional polycrystalline cobalt $(100 \mu \mathrm{m})(-)^{[44]}$. Solution: $0.25 \mathrm{~mol} \mathrm{dm}^{-3}$ $\mathrm{Na}_{2} \mathrm{SO}_{4}$ at room temperature and $\mathrm{pH} 10.5$. The oxygen level of the solution was reduced with bubbling nitrogen gas $15 \mathrm{~min}$ before and during the test.

Figura 5. Curvas potenciodinámicas para cobalto nanocristalino $(67 \mathrm{~nm})(---)$ y cobalto policristalino convencional $(100 \mu \mathrm{m})(-)^{[44]}$. Disolución: $0.25 \mathrm{~mol} \mathrm{dm}{ }^{-3} \mathrm{Na}_{2} \mathrm{SO}_{4}$ a temperatura ambiente y $\mathrm{pH} 10,5$. El nivel de oxigeno de la disolución fue reducido burbujeando nitrógeno gas 15 min antes $y$ durante el experimento. 
Potentiodynamic anodic polarization curves of these specimens are shown in figure 5 .

There were no significant differences in the chemical composition of NC and CG cobalt and the authors found that the slightly potential shift towards negative values from the equilibrium potential in cobalt $\mathrm{NC}$ was due to the different structure of the two specimens. At negative potentials the corrosion attack easily starts on the large number of defects presented on NC materials such as grain borders and triple unions which possess high energy and favours the corrosion process.

Jung et al. ${ }^{[46]}$ have studied the same compounds using electrochemical impedance spectroscopy and polarization in $0.1 \mathrm{M} \mathrm{H}_{2} \mathrm{SO}_{4}$ solution. In a similar fashion to Aledresse and Alfantazi ${ }^{[45]}$, they found that both microcrystalline (MC) and NC cobalt and Co$\mathrm{P}$ alloys exhibited active dissolution processes. While the anodic polarization curve for $\mathrm{NC}$ cobalt was almost identical to that of its MC counterpart, AC impedance measurements revealed that the charge transfer resistance of cobalt nanoparticles was slightly smaller than that of microparticles of cobalt. The addition of phosphorus leads to a remarkable increase of the corrosion resistance however, the $\mathrm{NC} \mathrm{Co-P}$ was deteriorated by corrosion pitting at high anodic potentials. The conclusion was that the presence of phosphorus played a major role to enhance the corrosion resistance by hindering the anodic dissolution kinetics of the cobalt surface only near the $E_{\text {corr }}$ but at high anodic overpotentials a deteriorating pitting corrosion occurred.

A recent study by Wang et al. ${ }^{[47]}$ concluded that the electrochemical corrosion and passive behaviour of $\mathrm{NC}$ cobalt coatings occurs via a diffusion-controlled mechanism and that higher grain boundary density in $\mathrm{NC}$ materials strongly affected their corrosion behaviour. In $\mathrm{NaOH}$ or $\mathrm{NaCl}$ solutions, the corrosion resistance of the NC structure improved when compared with their CG counterpart. This is due to the higher grain boundary density in the NC materials which quickly forms a continuous protective and duplex passive film of $\mathrm{Co}(\mathrm{OH})_{2} / \mathrm{Co}_{3} \mathrm{O}_{4}$. In $\mathrm{HCl}$ or $\mathrm{H}_{2} \mathrm{SO}_{4}$ acids the passive process is not evident; higher grain boundary can accelerate corrosion by providing high-density active sites for preferential attack when NC cobalt materials are exposed to such corrosive environment. The controversial experimental results on $\mathrm{NC}$ cobalt coatings in various corrosive media can be reasonably explained by the positive or negative effect of the high-density network of grain boundaries. This can be visualised in the model of corrosion in $\mathrm{NC}$ in several media, proposed by the authors and shown in figure 6 .

This behaviour observed in cobalt $\mathrm{NC}$ can be extrapolated to other NC materials, as it was mentioned above the electrolyte plays an important

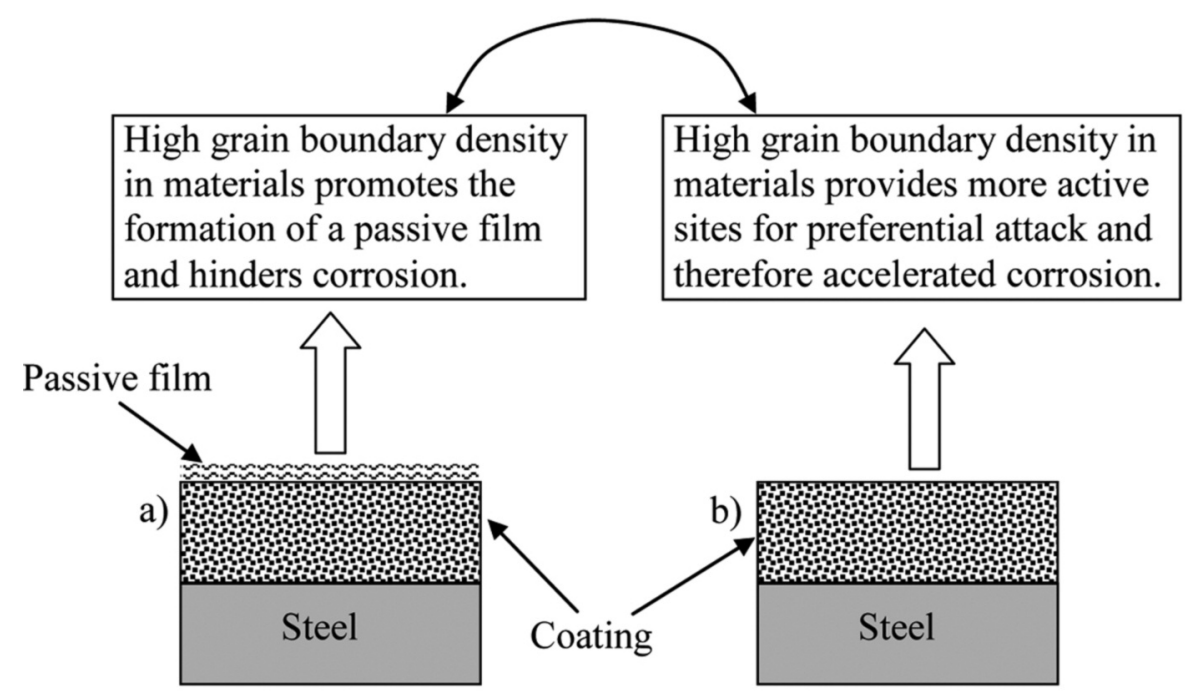

Figure 6. Model for the corrosion mechanism of nanocrystalline cobalt coatings in different corrosion media: (a) positive effect of high grain boundary density alkaline media and (b) negative effect of high grain boundary density on anticorrosive process in acid media ${ }^{[46]}$.

Figura 6. Modelo del mecanismo de corrosión de depósitos de cobalto nanocristalino en diferentes medios: (a) efecto positivo de alta densidad de bordes de grano en medio alcalino y (b) efecto negativo de alta densidad de bordes de grano en medio ácido [46]. 
THE CORROSION BEHAVIOUR OF NANOGRAINED METALS AND ALLOYS

EL COMPORTAMIENTO DE LA CORROSIÓN DE LOS METALES Y ALEACIONES NANOGRANULADOS

Table II. Literature corrosion parameters reported for cobalt

Tabla II. Parámetros de corrosión del cobalto extraídos de la literatura

\begin{tabular}{|c|c|c|c|c|c|}
\hline Sample & $\mathrm{E}_{\text {corr }}$ vs. SCE/mV & $\mathrm{j}_{\text {corr }} / \mu \mathrm{A} \mathrm{cm}^{-2}$ & $\mathrm{R}_{\mathrm{p}} / \mathrm{k} \Omega \mathrm{cm}^{-2}$ & Conditions & Reference \\
\hline Co $(18$ nm) & -1022 & 0.19 & 1.567 & $10 \%$ wt. $\mathrm{NaOH}$ & [47] \\
\hline Co $(3 \mu \mathrm{m})$ & -1032 & 0.36 & 0.824 & & \\
\hline Co $(18 \mathrm{~nm})$ & 409 & 0.31 & 0.518 & $10 \%$ wt. $\mathrm{HCl}$ & \\
\hline Co $(3 \mu \mathrm{m})$ & -391 & 0.11 & 1.509 & & \\
\hline Co $(67 \mathrm{~nm})$ & -550 & 0.86 & NA & $0.25 \mathrm{~mol} \mathrm{dm}^{-3}$ & {$[45]$} \\
\hline Co $(100 \mu \mathrm{m})$ & -523 & 1.84 & NA & $\mathrm{Na}_{2} \mathrm{SO}_{4}$ at $\mathrm{pH} 10$ & \\
\hline Co-P (50 nm) & -567 & 19.3 & NA & & \\
\hline Co $(20 \mathrm{~nm})$ & -405 & NA & 0.07 & $0.1 \mathrm{~mol} \mathrm{dm}^{-3}$ & {$[46]$} \\
\hline Co $(35 \mu \mathrm{m})$ & -410 & NA & 0.097 & $\mathrm{H}_{2} \mathrm{SO}_{4}$ & \\
\hline Co-P (10 nm) & -360 & NA & 1.136 & & \\
\hline
\end{tabular}

NA, not available.

role in the corrosion resistance of these materials. Table II shows different corrosion parameters of NC obtained from different authors in different electrolyte media compared with CG.

A slight decrease in the corrosion rate can be observed in the case of cobalt in alkaline media but an increase in acid. In this case, the addition of phosphorous to create an alloy is more important than lowering the grain size to obtain lower corrosion rates.

\subsection{Copper and its alloys}

Coarse grain copper is widely used in electrical and electronic devise despite the fact it readily corrodes in a variety of environments, despite its relative nobility ${ }^{[48]}$. NC copper has considerable uses in microelectromechanical systems ${ }^{[49]}$ and printed wiring board manufacture ${ }^{[50 \text { and } 51]}$. Yu et al. ${ }^{[52]}$ have studied the corrosion behaviour of $\mathrm{NC}$ copper foil in $0.1 \mathrm{M}$ $\mathrm{NaOH}$ solution and found electrodeposited copper foils with grain sizes between $45 \mathrm{~nm}$ to $1 \mu \mathrm{m}$ and conventional CG cold-rolled copper, displayed activepassive-transpassive corrosion behaviour. The study was carried out by potentiodynamic polarization curves and authors concluded that the general shape of the curves was not affected by grain size reduction. The corrosion parameters obtained from the polarization curves shown in table III confirm that these parameters changed little with the grain size.

The general corrosion behaviour of ultrafinegrained (UFG) Cu with a mean grain size of $200 \mathrm{~nm}$ produced by severe plastic deformation has been

Table III. Corrosion parameters reported for different grain size of copper

Tabla III. Parámetros de corrosión para cobre con diferente tamaño de grano

\begin{tabular}{lcccc}
\hline Sample & $\mathbf{E}_{\text {corr }}$ vs. SCE $/ \mathbf{m V}$ & $\mathbf{j}_{\text {passive }} / \boldsymbol{\mu A} \mathbf{~ c m}^{-2}$ & Conditions & Reference \\
\hline $\mathrm{Cu}(45 \mathrm{~nm})$ & -511 & 6.15 & $0.1 \mathrm{~mol} \mathrm{dm}^{-3} \mathrm{NaOH}$ & [52] \\
$\mathrm{Cu}(250 \mathrm{~nm})$ & -532 & 4.85 & & \\
$\mathrm{Cu}(1 \mu \mathrm{m})$ & -516 & 4.42 & & \\
$\mathrm{Cu}(3 \mu \mathrm{m})$ & -570 & 3.23 & & \\
\hline
\end{tabular}


reported ${ }^{[53}$ and 54$]$. The corrosion study was done in a solution containing: $30 \times 10^{-3} \mathrm{dm}^{-3} \mathrm{HCl}, 10 \times 10^{-3} \mathrm{dm}^{-3}$ $\mathrm{CH}_{3} \mathrm{COOH}$ and $410 \times 10^{-3} \mathrm{dm}^{-3} \mathrm{H}_{2} \mathrm{O}$ at $0.41 \mathrm{pH}$. This electrolyte was chosen due to its high sensitivity to the surface state of copper since high potential regions are preferentially attacked. The authors consider that the shape of the polarization curves and type of corrosive attack remains the same for both, the UFG and the CG copper. Some differences such as value of the anodic current, are largely determined by the grain boundary also depend on the heat treatment applied to the UFG material. Highly localized corrosion in ordinary CG copper with relatively large grains size is almost entirely associated with grain boundaries. Homogeneity of corrosive damages seems to be the main advantage of UFG in comparison to conventional polycrystals, susceptible to localized intergranular corrosion. This advantage is limited, however, by two factors, the low thermal stability of the UFG structure and the higher dissolution rate.

When nickel is added to copper, the alloy is mechanically stronger and the corrosion resistance in sea and polluted water improves. Barbucci et al. ${ }^{[55]}$ reported a study of the $\mathrm{NC} \mathrm{Cu}_{90} \mathrm{Ni}_{10}$ alloy in neutral solution containing chlorides and showed that the grain size plays an important role in the value of the breakdown potential. The potential shifted to more negative values in $\mathrm{NC}$ alloys with respect to $\mathrm{CG}$ alloys. The most important conclusion of this work was that the passive oxides, which grow on the $\mathrm{NC}$ metal surface, are not very well compacted in comparison with the passive layer in CG alloys. The grain boundary is always seen as a critical zone where the growth of a regular oxide layer could encounter difficulties due to the metal's gel-like structure. The smaller the grain size, the higher the amount of grain boundary structures and the more difficult for the passive film to grow on this active site which can act as promoter of defective passivity layer formation. Table III shows corrosion potential values and the corresponding passive current for copper materials having different grain sizes. These data shows that as the grain size decreases, the corrosion potential shifts towards positive values and the passive current increases due to corrosive agents. The data also suggest that there are not important fundamental differences in this material in its NC presentation.

\subsection{Other metals}

The corrosion behaviour of other NC metals including iron, stainless steel, zinc and titanium has also been reported. For example, Afshari et al. ${ }^{[56]}$ have studied the corrosion of iron coatings and the effect of the grain size of electrodeposited iron NC and compared with microcrystalline (MC) samples in alkaline solution. The authors found that a decrease in the grain size slowed down the corrosion rate and explained this behaviour by arguing that $\mathrm{OH}^{-}$ions are adsorbed on the NC surface involving the following chemical-electrochemical-chemicalelectrochemical (CECE) corrosion mechanism:

$$
\begin{array}{lr}
\mathrm{Fe}+\mathrm{H}_{2} \mathrm{O} \rightarrow \mathrm{Fe}\left(\mathrm{H}_{2} \mathrm{O}\right)_{\text {ads }} & \text { Chemical (4) } \\
\mathrm{Fe}\left(\mathrm{H}_{2} \mathrm{O}\right)_{\text {ads }} \rightarrow \mathrm{Fe}(\mathrm{OH})^{+}+\mathrm{H}^{+}+2 \mathrm{e}^{-} & \text {Electrochemical (5) } \\
\mathrm{Fe}(\mathrm{OH})^{+}+\mathrm{OH}^{-} \rightarrow \mathrm{Fe}(\mathrm{OH})_{2} & \text { Chemical (6) } \\
\mathrm{Fe}(\mathrm{OH})_{2} \rightarrow \gamma \mathrm{FeOOH}+\mathrm{e}^{-}+\mathrm{H}^{+} & \text {Electrochemical (7) }
\end{array}
$$

The corrosion resistance improved, perhaps due to the rapid formation of continuous iron oxyhydroxide films on the defects of the crystalline surface. The transport of ions through the passive films took place by migration and/or diffusion through the defects, forming more protective passive layers inside the nanocrystal. The authors attributed this mechanism to the wide energy band caused by decreasing the grain size. Figure 7 shows a large passive zone and shift of the corrosion peak towards more positive values together with a decay of the corrosion current as the grain size decreases.

The calibration curve shows that as the grain size decreases the adsorption of increases and the passive current decreases. Elkedim et al. ${ }^{[57]}$ arrived to similar conclusions by studying the behaviour of a distinct mixture of the $\mathrm{NC}$ iron coatings and compared them with 'as-received' CG iron. Their work indicate that an increase of NC iron fraction improves the characteristics of the corrosion resistance and it may be attributed to the better consolidation and triple junction content of $\mathrm{NC}$ iron.

The effect of nanocrystals and twin boundaries in stainless steel type 316 has been studied and found that the corrosion resistance depended to a great extent on the grain boundary structure ${ }^{[58]}$.

$\mathrm{NC}$ boundaries with a special channel structure reduced the corrosion resistance, while an extreme increase in corrosion resistance was observed on twin boundaries with a special low energy. Wang et al. ${ }^{[59]}$ studied the corrosion behaviour of NC surface of stainless steel type 304 using electrochemical scratch tests under potentiostatic condition. With this technique, when a passive layer is scratched in a corrosive solution, the exposed fresh metal surface increases the anodic current due to the electrochemical dissolution. When the scratching is 


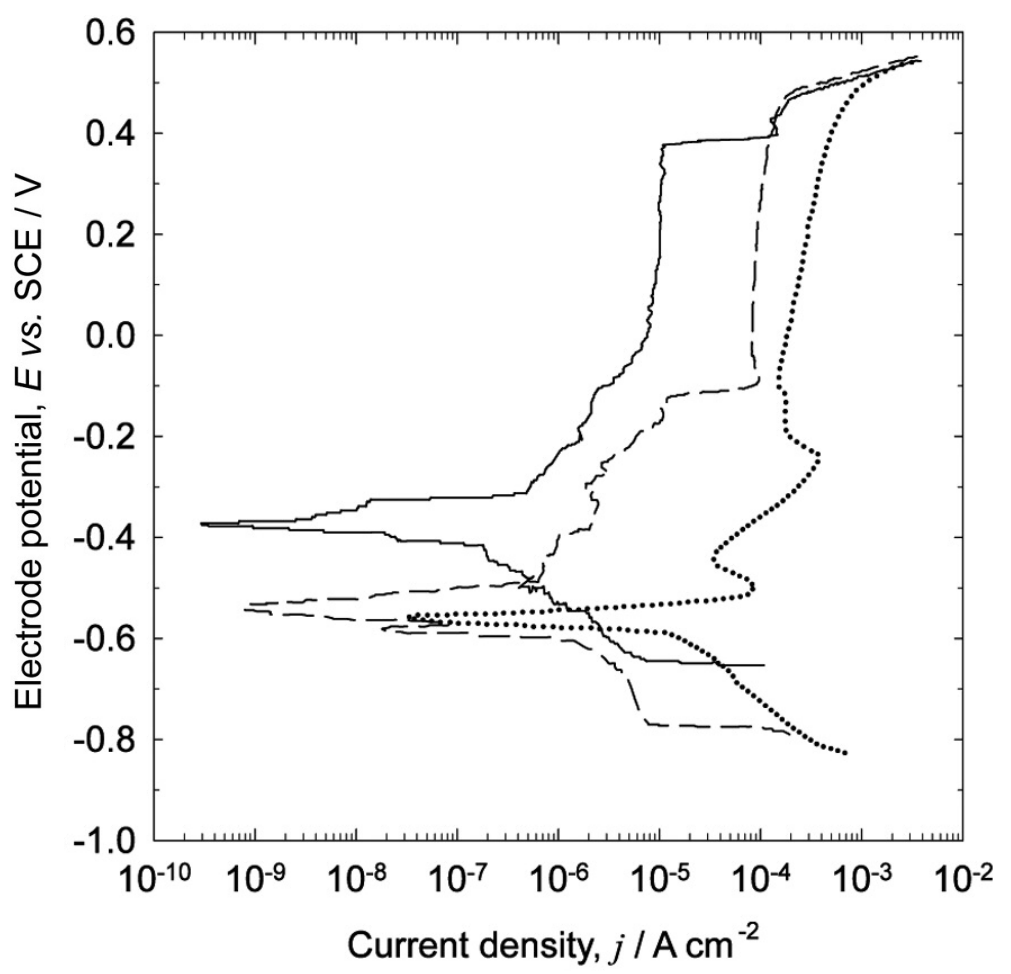

Figure 7. Potentiodynamic polarization curves of iron in $10 \%$ wt. $\mathrm{NaOH}$ solution: (-) $45 \mathrm{~nm},(---) 20 \mu \mathrm{m}$ and (....) $300 \mu \mathrm{m}$ [56].

Figura 7. Curvas de polarización potenciodinámicas de hierro en disolución $10 \%$ en peso. $\mathrm{NaOH}$ : (-) $45 \mathrm{~nm}$, (---) $20 \mu \mathrm{m}$ and (....) $300 \mu \mathrm{m}^{[56]}$.

completed, the current rapidly decreases due to the repassivation of the scratched surface. Using this concept the authors studied current vs. time curves in order to evaluate the repassivation capability of stainless steel 304 using sandblasting and annealing samples. Their results show that the samples having a NC formation become highly passive and the surface recovers its chemical stability.

The corrosion behaviour of other metals such as titanium and zinc has been studied to compare the ultra fine grain (UFG) structure or NC surface with the commercial CG metals. In the case of titanium, Zhu et al. ${ }^{[60]}$ investigated UFG and CG structures and concluded that UFG presented better corrosion resistance in $\mathrm{HCl}$ and $\mathrm{H}_{2} \mathrm{SO}_{4}$ solutions due to the rapid formation of passive films on the surface crystalline defects, including grain boundaries and dislocations.

Zinc is one of the most widely applied metal coatings for protection of steel against corrosion. Its success can be attributed to several factors such as its sacrificial nature, low cost, and ease of application. However, zinc coatings must be thick enough to endure attack in a corrosive environment. There is a significant interest in the development of zinc $\mathrm{NC}$ as a thin layer to improve corrosion resistance. Youssef et al. ${ }^{[61]}$ used a pulsed current to electrodeposit zinc $\mathrm{NC}$ on steel and compared its corrosion behaviour against that of an electrogalvanized steel sample. They concluded that zinc NC deposits exhibit a lower corrosion rate than the electrogalvanized zinc because the oxide film formed on the surface was more protective. The zinc NC surface corroded forming a discrete etch pit morphology, while a uniform corrosion was observed on the electrogalvanized steel surface. This result contradicts the findings reported by other authors.

Titanium and its alloys are used for implant materials in medical and dental fields because of their biocompatibility, corrosion resistance and specific strength compared with other metallic implant materials ${ }^{[62]}$. Alloys of $\mathrm{Ti}-\mathrm{Zr}$ have been studied in $\mathrm{NaCl}$ solution and the effect of the zirconium content in the polarization curves have shown that the corrosion resistance increases with the content of zirconium $^{[63]}$. This has been attributed to the rapid formation of passive films of $\mathrm{TiO}_{2}$ and $\mathrm{ZrO}_{2}$ on the surface. The passive surface is dozens of nano meters thick and restrings the exit of metal ions from the metal surface towards the solution minimizing the corrosion effects. 
$\mathrm{NC}$ titanium prepared by equal channel angular pressing (ECAP) show similar behaviour that other metals, therefore UFG titanium has lower corrosion current densities and more positive corrosion potential that CG titanium. The reason is again, the rapid formation of passive films at the surface of the crystalline defects in the case of UFG and the segregation of impurities to grain boundaries in the case of CG, which produce, in this case, an acceleration of the corrosion.

\subsection{Complex alloys}

Although the corrosion resistance of metallic amorphous alloys has been studied in detail, the corrosion behaviour of NC alloy materials containing various metals have received less attention. The majority of the studies have been performed in aqueous acidic media where some of these alloys have shown extremely high corrosion resistance. Total or partial crystallization, can form NC phases in the amorphous matrix and the corrosion behaviour deteriorate. However, the effects are strongly influenced by several factors such as the chemical composition of the alloys, size and composition of the precipitates, preparation method and type of corrosion, making it difficult to establish a general corrosion behaviour mechanism in these systems.

Souza et al..$^{\left[64 \text { and }{ }^{65]} \text { have studied the corrosion }\right.}$ resistance of different alloys such as $\mathrm{Fe}-\mathrm{M}-\mathrm{B}$ and Fe-M-B-Cu where $\mathrm{M}$ is a transition metal of the two first series in the periodical table. These alloys have attracted substantial attention due to their soft magnetic properties that indicate their importance in applications such as power transformers, data communication, interface components, electromagnetic interference prevention components, magnetic heads, sensor, magnetic shielding and reactors ${ }^{[66]}$. The effects of the composition, structure and magnetic properties of these materials have been extensively reported. However, the corrosion resistance and the effect of corrosion on the saturation magnetic flux density have not been extensively evaluated. It is important to consider this effect since normal atmospheric corrosion and pitting corrosion are unavoidable in many applications where these alloys are currently used. In the work of Souza et al. ${ }^{[67]}$, the effect of the composition and the crystallization of the alloys have been studied and the most important factor against corrosion has been attributed to the composition. Materials with niobium or silicon improve the corrosion resistance due to the formation of very stable passive films on the surface of the alloys and, the crystallization process normally decreased the corrosion resistance for every alloy composition analyzed. Another important aspect is the decrease in the saturation of magnetic flux density with the immersion in corrosive solution and the correlation of this decrease with the corrosion resistance. Other studies on amorphous materials with soft magnetic properties have shown that an equal decrease in the soft magnetic properties occur during consecutive immersions in a corrosive solution of $0.1 \mathrm{~mol} \mathrm{dm}^{-3} \mathrm{H}_{2} \mathrm{SO}_{4}{ }^{[68]}$. For this reason the corrosion control phenomena in these alloys is necessary for applications where magnetic flux density is important. Another example of a type magnetic alloy found in the literature includes amorphous compositions such as $\mathrm{Ni}-\mathrm{Cr}$-(Mo or Ta)-P-B which are obtained by a mould casting method and by rapidly quenching. The alloys show identical corrosion resistance in $6 \mathrm{~mol} \mathrm{dm}{ }^{-3} \mathrm{HCl}$, but can improve up to three times depending on the size of the precipitates ${ }^{[69]}$. When the size of the precipitated nanocrystals are $2 \mathrm{~nm}$, the corrosion rate is much lower than when they are $20 \mathrm{~nm}$. The extremely fine $\mathrm{NC}$ microstructure results in a uniform distribution of impurities and provides a homogeneous substrate for the formation of a stable passive layer. $\mathrm{Zr}-\mathrm{Cu}-\mathrm{Ni}-\mathrm{Al}$ alloys show no significant differences in corrosion resistance in aqueous solutions between the amorphous and NC state, but the oxidation resistance in air, improved significantly with the transition from the amorphous to $\mathrm{NC}$ microstructure ${ }^{[70]}$. Other interesting studies on partially nanocrystallised zirconium alloys ${ }^{[71]}$ have shown that these materials exhibit greater mechanical strength than conventional polycrystalline alloys while at the same time retaining the macroscopic corrosion resistance of the fully amorphous state. High strength and good corrosion resistance in these new materials can be obtained and depends critically on the nanocrystal size. The composition of the alloy is also an important factor, for example the amorphous and crystalline $\mathrm{Zr}-\mathrm{Cu}-\mathrm{Ni}$ and aluminium alloys are very sensible to corrosion if compared with pure crystalline zirconium.

The corrosion resistance of $\mathrm{Ni}-\mathrm{Mo}-\mathrm{B}$ alloy in $0.8 \mathrm{~mol} \mathrm{dm}^{-3} \mathrm{KOH}$ solution showed to be less sensitive when compared with the counterpart CG material. This behaviour was related to their small grain size and to the homogeneous single phase microstructure. The structure of this material was very uniform and easily formed ${ }^{[72]}$.

In another study by Cremaschi et al. ${ }^{[73]}$ three different alloys of $\mathrm{FeSiB}$ were analyzed: amorphous, nanocrystalline and crystalline, by potentiodynamic 
anodic polarization technique in alkaline and neutral chloride media. The authors concluded that the electrochemical behaviour of the materials strongly depends on the $\mathrm{pH}$ of the medium. Generalized corrosion occurs at neutral $\mathrm{pH}$ values but a passive region followed by an abrupt increase of current occurs in alkaline media.

A similar behaviour was found by Zeiger et al. ${ }^{[74]}$ on the study of $\mathrm{FeAl}_{8}$ alloys in $\mathrm{pH} 1$ solutions. The results showed that the density of defects promotes the metal dissolution. When the $\mathrm{pH}$ increases to 6 the development of a protective oxide film is faster in the NC alloy and a shift to cathodic potentials is observed. The explanation could be due to the faster dissolution of aluminium at the grain boundaries which creates strong concentration gradient of aluminium between the surface and the bulk of the alloy. The authors claimed that if the diffusion of the aluminium ions is fast in the grain boundaries, the layer formed on the $\mathrm{NC}$ material will offer a better corrosion protection than on the polycrystalline alloy.

\section{CONCLUSIONS}

From the different studies on nanocrystalline metals and comparing their behaviour with microcrystalline or coarse grain morphology, the following information can be summarized:

- The general observation is that in a weak acid and alkaline electrolytes the NC materials form and maintain a good quality passive layer, which deteriorates in strong aggressive electrolytes, with respect to the micropolycrystalline materials.

- The increased attack to the grain borders, which is one of the main corrosion mechanisms in polycrystalline materials, is very noticeable in nanocrystalline materials. Some reasons for this behaviour includes: a) the solute dilution effect by grain size refinement, b) crystallographic texture changes with decreasing grain size and c) grain size-dependent of the passive layer formation.

- If the MC material contains impurities they will naturally migrate to the grain borders and precipitate. In the case of the $\mathrm{NC}$ materials the much smaller grain size causes the impurities to diffuse and homogenised by segregation creating stronger and more stress and corrosion resistant materials.

- Another important factor to highlight is that the properties of the $\mathrm{NC}$ material depend to a great extend on the preparation method; $\mathrm{NC}$ materials prepared by electrodeposition present different ratio between the grain borders and triple junctions than those prepared by other technologies. Therefore, materials with similar grain size but prepared using different methods will have different corrosion velocities.

- The investigations suggest that an increase in the corrosion resistance occurs due to an increase in the volume fraction and in many cases due to a low sigma boundary coincidence site lattice. This could have important implications in engineering $\mathrm{NC}$ materials thus increasing the frequency of this type of especial bonds and increasing not only the corrosion resistance but also enhancing the mechanical properties as a result of the dislocation arrangements in the grain boundary regions.

As a general conclusion, nanocrystalline materials seem to present better behaviour against corrosion when a passive layer is formed on their surface. This passive layer is more uniform and durable than the similar layer formed on microcrystalline or coarse grain materials. The most important differences between NC and no NC materials against corrosion seems to be due to factors such as grain boundaries and triple unions; their number and distribution in the material are key to determining the likely corrosion rate and corrosion resistance.

\section{FURTHER WORK}

Corrosion studies on NC materials are still very limited and scattered in the literature. Our understanding of the nature of the corrosion behaviour of NC materials still await further experimental and theoretical developments to determine the relationship between grain size, structure, corrosion rates, e.g. information on triple and double junctions.

NC materials show the potential to improve the corrosion resistance. As well as a continuous high level of fundamental research, there is need for applied research to rapidly assess this new technology and to provide a fast technology transition. Unfortunately, there is still a lack of understanding in the fundamental aspects of the corrosion mechanisms in such materials. In particular, an understanding is needed in why a particular critical size, composition, spacing and 
structure of the nanocrystals control both, the corrosion resistance, the formation of micrometre scale local corrosion pits and the dissolution properties in strong reducing acids.

Another important aspect waiting to be resolved in future investigations is the effect of the composite structure and composition of the $\mathrm{NC}$ alloys in the corrosion resistance. The case of nanocrystals embedded in amorphous matrixes including changes in the lattice parameters and the effects of the curved surfaces as well as the comparison with the micro, bulk or coarse materials of the same composition.

The techniques used in the corrosion analysis of nanocrystalline materials are classical techniques used for micro a coarse grain materials such as linear polarization, cyclic voltammetry and open-circuit potential measurements. New techniques such as scanning electron microscopy, atomic force microscopy and scanning electrochemical microscopy should allow more accurate analysis of the relationships between corrosion resistance and the parameters such as grain borders, triple unions and their volume increase with respect to the nanocrystalline materials.

\section{Acknowledgments}

The authors gratefully acknowledge financial support of the Spanish Ministery of Science and Education for a grant to P. Herrasti which enabled a visit to the University of Southampton.

\section{REFERENCES}

[1] A. Gromov and V. Vereshchagin, J. Eur. Ceram. Soc. 24 (2004) 2879-2884.

[2] T. X. Fan, S. K. Chow and D. Zhang, Progr. Mater. Sci. 54 (2009) 542-659.

[3] A. Dasari, Z. Z. Yu and Y. W. Mai, Polymer 50 (2009) 4112-4121.

[4] R. Gangopadhyay and A. De, Chem. Mater. 12 (2000) 608-622.

[5] J. G. Gonzalez-Rodriguez, M. A. Lucio-Garcia, M. E. Nicho, R. Cruz-Silva, M. Casales, and E. Valenzuela, J. Power Sourc. 168 (2007) 184-190.

[6] C. Ponce de León, D. V. Bavykin and F. C. Walsh, Electrochem. Commun. 8 (2006) 1655-1660.

[7] C. G. Granqvist, Sol. Energ. Mater. Sol. Cell 91 (2007) 1529-1598.

[8] D. V. Bavykin and F. C. Walsh, Titanate and Titania Nanotubes; Synthesis, Properties and Applications, Royal Society of Chemisty, Cambridge, UK, 2010.
[9] M. Conte, P. P. Prosini, and S. Passerini, Mater. Sci. Eng. B 108 (2004) 2-8.

[10] S. Hamdani, C. Longuet, D. Perrin, J. M. LopezCuesta and F. Ganachaud, Polym. Degrad. Stabil. 94 (2009) 465-495.

[11] G. A. Jimenez and S. C. Jana, Compos. Appl. Sci. Manuf. 38 (2007) 983-993.

[12] Y. Yun, Z. Dong, V. N. Shanov, A. Doepke, W. R. Heineman, H. B. Halsall, A. Bhattacharya, D. K. Y. Wong and M. J. Schulz, Sensor Actuat. B Chem. 133 (2008) 208-212.

[13] G. A. Rivas, M. D. Rubianes, M. L. Pedano, N. F. Ferreyra, G. Luque and S. A. Miscoria, Electroanalysis 19 (2007) 823-831.

[14] V. Thavasi, G. Singh and S. Ramakrishna, Energ. Environ. Sci. 1 (2008) 205-221.

[15] F. Cheng, Y. Su, J. Liang, Z. Tao and J. Chen, Chem. Mater. 22 (2010) 898-905.

[16] Nanomedicine. National Horizon Scanning Unit Emerging Technology Bulletin (2007). HealthPACT Secretariat Department of Health and Ageing, February 2007. http://www. horizonscanning.gov.au Accessed 20 September 2011.

[17] Nanotechnology and nanoscience: economic aspects (2011) The Institute of International Economy http://iei.ua.es/nanotecnologia Accessed 20 September 2011.

[18] United States National Nanotechnology Initiative. $h t t p: / / w w w . n a n o . g o v / h t m l / f a c t s / f a q s . h t m l$ Accessed 20 September 2011.

[19] R. Baan, K. Straif, Y. Grosse, B. Secretan, F. El Ghissassi and V. Cogliano, Lancet. Oncol. 7 (2006) 295-296.

[20] D. V. Bavikyn, J. M. Freidrich, A. A. Lapkin and F. C. Walsh, Chem. Mater. 18 (2006) 1124-1129.

[21] S. Banerjee, T. Hemraj-Benny and S. S. Wong, Adv. Mater. 17 (2005) 17-29.

[22] R. Birringer, Mater. Sci. Eng. 117 (1989) 33-43.

[23] G. Palumbo, S. J. Thorpe and K. T. Aust, Scripta Metall. Mater. 24 (1990) 1347-1350.

[24] Y. Zhou, U. Erb, K. T. Aust and G. Palumbo, Scripta Mater. 48 (2003) 825-830.

[25] O. Elkedim, Electrochemical Corrosion Behaviour of Nanocrystalline Materials in Eftekhari A, (ed) Nanostructured materials in Electrochemistry Wiley-VCH Weinheim Germany, 2008, pp. 291-317.

[26] L. Wang, J. Zhang, Y. Gao, Q. Xue, L. Hua and T. Xu, Scripta Mater. 55 (2006) 657-660.

[27] W. A. Badawy, K. M. Ismail and A. M. Fathi, Electrochim Acta 50 (2005) 3603-3608.

[28] W. A. Badawy, F. M. Al-Kharafi and J. R. AlAjmi, J. Appl. Electrochem. 30 (2000) 693-704.

[29] S. Wang, R. Rofagha, P. H. Roberge and U. Erb, Proceedings of the Symposium on Nanstructured 
THE CORROSION BEHAVIOUR OF NANOGRAINED METALS AND ALLOYS EL COMPORTAMIENTO DE LA CORROSIÓN DE LOS METALES Y ALEACIONES NANOGRANULADOS

Materials in Electrochemistry Electrochemical Society 95, 1995, pp. 244-255.

[30] P. Yong, Z. Yi-Chun, Z. Zhao-feng, H. Yong-li, L. Yan-guo and S. Chang-Qing, Transactions of Nonferrous Metals Society of China 17 (2007) 1225-1229.

[31] R. Rofagha, S. J. Splinter, U. Erb and N. S. McIntyre, Nanostruct. Mater. 4 (1994) 69-78.

[32] F. Gonzalez, A. M. Brennenstuhl, G. Palumbo, U. Erb and P. C. Lichtenberger, Mater. Sci. Forum. 225 (1996) 831.

[33] R. Mishra and R. Balasubramaniam, Corros. Sci 46 (2004) 3019-3029.

[34] I. Roy, H. W. Yang, L. Dinh, I. Lund, J. C. Earthman and F. A. Mohamed, Scripta Mater. 59 (2008) 305-308.

[35] J. A. Wharton, R. C. Barik, G. Kear, R. J. K. Wood, K. R. Stokes and F. C. Walsh, Corros. Sci. 47 (2005) 3336-3367.

[36] S. K. Ghosh, G. K. Dey, R. O. Dusane and A. K. Grover, J. Alloy. Compd. 426 (2006) 235-243.

[37] R. Rofagha, U. Erb, D. Ostrander, G. Palumbo and K. T. Aust, Nanostruct Mater 2 (1993) 1-10.

[38] S. J Splinter, R. Rofagha, N. S. MacIntyre and U. Erb, Surf Interface Anal. 24 (1996) 181-186.

[39] Y. Gao, Z. J. Zheng, M. Zhu and C. P. Luo CP, Mat. Sci. Eng. 381 (2004) 98-103.

[40] K. R. Sriraman, S. Ganesh Sundara Rama and S. K. Seshadri, Mat. Sci. Eng. 460 (2007) 39-45.

[41] M. Clarke and R. G. Elbourne, Electrochim. Acta 16 (1971) 1949-1954.

[42] T. P. Hoar, M. Talerman and E. Trad, Nature Physical Science 244 (1973) 41-42.

[43] S. A. M. Refaey, F. Taha and T. H. A. Hasanin, Electrochim. Acta 51 (2006) 2942-2948.

[44] S. H. Kim, K. T. Aust, U. Erb, F. Gonzalez and G. Palumbo, Scripta Mater. 48 (2003) 1379-1384.

[45] A. Aledresse and A. Alfantazi, J. Mater. Sci. 39 (2004) 1523-1526.

[46] H. Jung and A. Alfantazi, Electrochim. Acta 51 (2006) 1806-1814.

[47] L. Wang, Y. Lin, Z. Zeng, W. Liu, Q. Xuea, L. $\mathrm{Hu}$ and J. Zhang, Electrochim. Acta 52 (2007) 4342-4350.

[48] J. J. Steppan, J. A. Roth, L. C. Hall, D. A. Jeannotte and S. P. Carbone, J. Electrochem. Soc. 134 (1987) 175-190.

[49] M. R. Bahbanan, U. Erb and G. Palumbo, Nanostructured Metals for Enhanced Performance of LIGA Components in:S. M. Mukhopadhyay, et al. (eds.), Processing an Manufacturing Fifth Global Symposium, TMS, Warrendale, PA , John Wiley and Sons Ltd, 2004 p. 307.

[50] A. Robertson, U. Erb and G. Palumbo, Nanostruct. Mater. 12 (1999) 1035-1040.
[51] G. Palumbo, J. McCrea and U. Erb, Applications of Electrodeposited Nanostructures in: Nalwa HS (Ed.), Encyclopedia of Nanoscience and Nanotechnology, American Scientific Publishing, Stevenson Ranch, CA, 2004, p. 89.

[52] B. Yu, P. Woo and U. Erb, Scripta Mater. 56 (2007) 353-356.

[53] A. Vinogradov, T. Mimaki, S. Hashimoto and R. Valiev, Scripta Mater. 41 (1999) 319-326.

[54] H. Miyamoto, K. Harada, T. Mimaki, A. Vinogradov and S. Hashimoto, Corros. Sci. 50 (2008) 1215-1220.

[55] A. Barbucci, G. Farnè, P. Matteazzi, R. Riccieri and G. Cerisola, Corros. Sci. 41 (1999) 463-475.

[56] V. Afshari and C. H. Dehghanian, Corros. Sci. 51 (2009) 1844-1849.

[57] O. Elkedim, H. S. Cao and D. Guay, J. Mater. Process. Tech. 121 (2002) 383-389.

[58] A. Q. Lü, Y. Zhang, Y. Li, G. Liu, Q. H. Zang and C. M. Liu, Acta Metall. Sin. 19 (2006) 183-189.

[59] X. Y. Wang and D. Y. Li, Electrochim Acta 47 (2002) 3939-3947.

[60] A. Balyanov, J. Kutnyakova, N. A. Amirkhanova, V. V. Stolyarov, R. Z. Valiev, X. Z.Liao, Y. H. Zhao, Y. B. Jiang, H. F. Xu, T. C. Lowe and Y. T. Zhu, Scripta Mater. 51 (2004) 225-229.

[61] Kh. M. S. Youssef, C. C. Koch and P. S. Fedkiw, Corros. Sci. 46 (2004) 51-64.

[62] D. Kuroda, M. Niinomi, M. Morigana, Y. Kato and T. Yashiro, Mat. Sci. Eng. A 243 (1998) 244-249.

[63] W. G. Kim and H. C. Choe, Transactions of Nonferrous Metals Society of China 19 (2009) 1005-1008.

[64] C. A. C. Souza, J. E. May, L. Bolfarini, S. E. Kuri, M. F. de Oliveira and C. S. Kiminami, J. Non-Cryst. Solids 284 (2001) 99-104.

[65] C. A. C. Souza, M. F. de Oliveira, J. E. May,W. J. R. Botta, N. A. Mariano, S. E. Kuri and C. S. Kiminami, J. Non-Cryst. Solids 273 (2000) 282-288.

[66] C. A. C. Souza and C. S. Kiminami, J. NonCryst. Solids 219 (1997) 155-159.

[67] C. A. C. Souza, S. E. Kuri, F. S. Politti, J. E. May and C. S. Kiminami, J. Non-Cryst. Solids 247 (1999) 69-73.

[68] K. Peng, Y. Tang, L. Zhou, J. Tang, F. Xu and Y. Du, Phys. B Condens. Matter. 366 (2005) 110-115.

[69] A. Inoue and A. Makino, Nanostruct. Mater 9 (1997) 403-412.

[70] H. Habazaki, T. Sato, A. Kwashima, K. Asami and K. Hashimoto, Mat. Sci. Eng. A 304 (2001) 696-700. 
[71] U. Koster, D. Zander, A. Triwikantoro, A. Rudiger and L. Jastrow, Scripta Mater. 44 (2001) 1649-1654.

[72] D. Zander, U. Köster, N. Eliaz and D. Eliezer, Mat. Sci. Eng. A 294 (2000) 112-115.
[73] V. Cremaschi, I. Avram, T. Pérez and H. Sirkin, Scripta Mater. 46 (2002) 95-100.

[74] W. Zeiger, M. Schneider, D. Scharnweber and H. Worch, Nanostruct. Mater. 6 (1995) 1013-1016. 